\title{
ROLA PIELĘGNIARKI W EDUKACJI PODRÓŻUJĄCEGO ZRYZYKIEM ZACHOROWANIA NA WIRUSOWE ZAPALENIE WĄTROBY TYPU A
}

\section{THE ROLE OF A NURSE IN THE EDUCATION OF A TRAVELER AT RISK OF DEVELOPING HEPATITIS A}

\author{
Ewelina Krupowicz \\ studentka studiów doktoranckich, Zakład Zintegrowanej Opieki Medycznej, Wydział Nauk o Zdrowiu, Uniwersytet Medyczny w Białymstoku
}

https://orcid.org/0000-0003-0344-0266

DOI: https://doi.org/10.20883/pielpol.2021.20

\begin{abstract}
STRESZCZENIE
Do zakażenia dochodzi najczęściej drogą pokarmową, poprzez spożycie żywności i wody zanieczyszczonej kałem chorego. Najszybciej wirus rozwija się w krajach, w których występują bardzo złe warunki sanitarne, najczęściej do zakażenia dochodzi w Ameryce Południowej, Azji Południowo-Wschodniej czy Afryce. Oprócz tego HAV często występuje wśród osób pracujących w szpitalach, oczyszczalniach ścieków, szkołach czy też wśród handlowców. Wirusowe zapalenie wątroby typu A przenoszone jest za pośrednictwem brudnych rąk czy zakażonej żywności. Wizyta u pielęgniarki lub lekarza przed wyjazdem może ustrzec podróżującego od zakażenia lub pomóc we wcześniejszym rozpoznaniu choroby imożliwości szybszego wdrożenia leczenia. Celem pracy jest zwiększenie wiedzy na temat znaczenia profilaktyki i szczepień wśród podróżników zagrożonych zarażeniem się wirusowym zapaleniem wątroby typu $A$.
\end{abstract}

SŁOWA KLUCZOWE: WZW A, pielegniarka, profilaktyka, edukacja.

\section{Wstęp}

Wirus zapalenia wątroby typu A (WZW typu A) jest wirusem RNA z rodziny Picornaviridae, który wywołuje ostre stany zapalne miąższu wątroby. W sytuacji, kiedy dochodzi do infekcji, proces chorobowy nie przechodzi w postać przewlekłą czy też w stan przewlekłego nosicielstwa [1].

Do zakażenia dochodzi najczęściej drogą pokarmową, poprzez spożycie żywności i wody zanieczyszczonej kałem chorego. Fekalno-oralna droga przenoszenia zakażeń determinuje potencjalne grupy zawodowe o szczególnym narażeniu. Najczęściej należą do nich pracownicy, którzy mają stały kontakt z nieczystościami (w oczyszczalniach ścieków, obsługujący urządzenia kanalizacyjne), osoby pracujące w szpitalach, żłobkach, przedszkolach, w wojsku oraz podróżujące do stref endemicznego występowania choroby. Dobrze udokumentowaną grupą ryzyka zakażenia wirusem

\begin{abstract}
The most common infection occurs through the alimentary tract, through the consumption of food and water contaminated with the patient's faeces. The virus develops most rapidly in countries with very poor sanitary conditions, most often in South America, Southeast Asia or Africa. In addition, HAV is often found among people working in hospitals, sewage treatment plants, schools, or among traders. Hepatitis $A$ is transmitted through dirty hands or contaminated food. A visit to a nurse or doctor before departure can protect the traveler from infection or help in the earlier diagnosis of the disease and the possibility of faster treatment. The aim of the study is to increase knowledge and the importance of prophylaxis and vaccinations among travelers at risk of contracting hepatitis $\mathrm{A}$.
\end{abstract}

KEYWORDS: Hepatitis A, nurse, prevention, education.

WZW typu A stanowią handlowcy, którzy w celach zawodowych podróżują do krajów o pośredniej lub dużej endemiczności. Warto również nadmienić, że ponad $80 \%$ osób dorosłych w naszym kraju przebyła w dzieciństwie WZW typu A, uzyskując przy tym w naturalny sposób odporność [1, 2].

Ryzyko wystąpienia infekcji u niezaszczepionych podróżnych waha się od 3 do 20 przypadków na 1000 osób przebywających w krajach charakteryzujących się niskimi standardami sanitarnymi. Podróżni, którzy są najbardziej narażeni, najczęściej zamieszkują dane tereny przez co najmniej miesiąc. Około 10\% dzieci w wieku 1-14 lat i 20\% dorosłych w wieku 15-40 lat, którzy zakazili się WZW typu A, wymagało hospitalizacji. Umieralność osób zakażonych rośnie wraz z wiekiem i wynosi ponad 2\% u osób powyżej 40. r.ż. i 4\% u osób powyżej 60. roku życia [2, 3]. 
Wirus zapalenia wątroby typu A (HAV) jest wydalany z kałem w okresie od 1 do 2 tygodni przed wystąpieniem objawów klinicznych oraz do tygodnia po ich ustąpieniu. Wiremię, która trwa około 30 dni można wykryć krótko przed wystąpieniem objawów. W większości przypadków przebieg choroby jest łagodny. Hepatitisfulminans jest również skrajnie rzadkim powikłaniem [4].

\section{Cel pracy}

Celem pracy jest upowszechnienie wiedzy wśród podróżników na temat wirusowego zapalenia wątroby typu $A$, informowanie o zwiększonym ryzyku zakażenia poprzez wyjeżdżanie w tereny o zmniejszonym reżimie sanitarnym, objaśnienie zasad profilaktyki oraz znaczenia szczepień jako jednej z metod zapobiegających rozprzestrzenianiu się wirusa.

\section{Obraz kliniczny}

Zakażenie wirusem może być skąpoobjawowe, bez widocznej żółtaczki, poprzez klasyczne ostre WZW z typowymi wykładnikami biochemicznymi do niezwykle rzadko opisywanej postaci WZW o przebiegu piorunującym, który w skrajnych przypadkach może prowadzić do zgonu pacjenta $[5,6]$. Okres wylęgania choroby waha się od 2 do 6 tygodni (średnio 28 dni), po czym nagle pojawia się gorączka, ogólne osłabienie, nudności, bóle pod prawym łukiem żebrowym. Kilka dni później pojawia się żółtaczka, ciemne zabarwienie moczu, bóle głowy, brak apetytu. Zakażenie u małych dzieci jest łagodne lub bezobjawowe. U dorosłych choroba natomiast może przebiegać ciężko, objawy mogą utrzymywać się przez kilka tygodni, ale całkowity powrót do zdrowia następuje w ciągu kilku miesięcy [2].

Nabyta odporność pozostaje przez całe życie. Zakażenie WZW typu A endemicznie występuje głównie w rejonach Azji Środkowo-Wschodniej, Afryki i Ameryki Południowej [7]. Obecnie w Polsce każdego roku odnotowuje się około 100 przypadków zakażeń [3]. Nieco inaczej wygląda sytuacja w zachodniej części Europy, ponieważ wykazano, że na 1000 podróżujących mieszkańców z tej części świata miesięcznie diagnozowane są trzy przypadki z pełnoobjawowym obrazem choroby [1]. W Polsce w latach 70. XX wieku u prawie wszystkich dorosłych, którzy podjęli decyzję o wykonaniu badania na obecność WZW typu A, wykrywano przeciwciała anty-HAV IgG. Poprawa warunków sanitarnych i socjalno-ekonomicznych doprowadziła do zmniejszenia częstości HAV [8].

\section{Diagnostyka}

Przeciwciała anty-HAV w klasie IgM można rozpoznać na początku choroby. Wraz z zanikiem przeciwciał w klasie IgM pojawiają się przeciwciała anty-HAV w klasie IgG. Tak więc występowanie anty-HAV w klasie IgM stanowi podstawę do rozpoznania ostrego zakażenia, a w klasie IgG jest znacznikiem nabycia odporności na ponowne zakażenie wirusem HAV. Antygeny wirusa najczęściej znajdowane są w stolcu, płynach ustrojowych i wątrobie, ale jedynie w okresie ostrego zakażenia [1].

Podejrzewając zakażenie wirusem WZW typu A, należy na początku zapytać chorego, czy w ostatnim czasie przebywał na obszarach endemicznego występowania HAV oraz czy u innych osób widoczne były objawy świadczące o nabyciu choroby. Przeciwciała anty-HAV IgM w surowicy zazwyczaj pojawiają się równolegle z objawami chorobowymi i zanikają po około 6-12 miesiącach od początku choroby. Przeciwciała anty-HAV IgG w surowicy praktycznie nie są przydatne w ocenie klinicznej chorego, wykorzystywane są jedynie w badaniach epidemiologicznych i do oceny stanu uodpornienia. Badania HAV-Ag i HAV-RNA praktycznie nie są wykonywane [4].

\section{Rola pielęgniarki w edukacji podróżującego do krajów endemicznego występowania wirusa}

Pielęgniarka powinna poinformować podróżującego o możliwości zaszczepienia się przeciwko WZW typu A oraz o schemacie szczepień, który składa się z dwóch dawek - druga dawka podawana jest 6-12 miesięcy od pierwszego szczepienia [5]. Zgodnie z informacją producenta druga dawka szczepionki Avaxim może być podana do 36 miesięcy po pierwszej dawce, natomiast druga dawka szczepionki Havrix Adult może być podana nawet do 5 lat od podania pierwszej dawki. Pierwszą dawkę szczepionki należy przyjąć przynajmniej 2-4 tygodnie przed planowanym wyjazdem. WHO nie zaleca dawek przypominających, ponieważ poziom przeciwciał wytworzonych po szczepieniu podstawowym utrzymuje się przez okres co najmniej 25 lat. W Polsce dostępne są również szczepionki skojarzone uodparniające przeciw WZW A i B w jednym wkłuciu (wymagają podania trzech dawek w cyklu 0-1-6 miesiąc). Dla szczepionki skojarzonej WZW A i $B$ istnieje również przyspieszony schemat szczepienia: 0, 7, 21 dzień oraz jednorazowa dawka uzupełniająca po 12 miesiącach [2]. Iniekcję można wykonać w Punktach Szczepień Wojewódzkich Stacji Sanitarno-Epidemiologicznych, przychodniach lekarza rodzinnego lub innych punktach szczepień, należy również podkreślić, że szczepienia nie są refundowane przez Narodowy Fundusz Zdrowia [9]. Szczepionki przeciw WZW A zawierają inaktywowany wirus HAV. 
Inną ważną kwestią jest poinformowanie podróżującego o konieczności przestrzegania zasad higieny osobistej, zwłaszcza w kraju, w którym występuje duże ryzyko zakażenia. Zaleca się dokładne mycie rąk po wyjściu z toalety, przed każdym posiłkiem, unikanie ryzykownych zachowań seksualnych, w tym kontaktów oralno-analnych. Aby uniknąć zakażenia na HAV należy przestrzegać zasad higieny podczas przygotowywania jedzenia i w miarę możliwości poddawania ich zabiegom termicznym bezpośrednio przed spożyciem. Pamiętać także o myciu owoców i warzyw, w tym tych, które są opakowane. Jeśli to możliwe wymagać od osób sprzedających, aby żywność nieopakowana podawana była w rękawiczkach jednorazowych. Myć i dezynfekować sprzęt, miejsca i inne przedmioty przy użyciu preparatów działających na bazie czynnego chloru [9]. Kąpiel w wodzie zanieczyszczonej HAV również grozi zakażeniem. W przebiegu WZW A występuje krótki okres wiremii, dlatego HAV można zarazić się parenteralnie przez igły do akupunktury, tatuażu oraz podczas przetaczania osocza lub czynnika VIII, jednak są to przypadki, które zdarzają się sporadyczne [10].

Łatwość z jaką może dojść do zakażenia na WZW typu A, wynika z oporności wirusa na wiele czynników zewnętrznych np.: na kwas octowy, fosforowy, związki fenolu i alkohole. $\mathrm{W}$ temperaturze od $-20^{\circ} \mathrm{C}$ do $+4^{\circ} \mathrm{C}$ wirus może zachować swoją stabilność przez wiele lat. Wysuszony w temperaturze pokojowej lub jeśli znajdzie się w wodzie, na owocach morza lub w ściekach jest zdolny wywołać zakażenie jeszcze przez wiele tygodni. W procesie pasteryzacji mleka w temperaturze $60-63^{\circ} \mathrm{C}$ ulega inaktywacji dopiero po dziesięciu godzinach. Nie ulega całkowitemu zobojętnieniu w procesie technologicznego wytwarzania czynnika VIII, nawet przy ogrzewaniu go do temperatury $60^{\circ} \mathrm{C}$ przez dziesięć godzin. Niewrażliwy jest na chloroform i $20 \%$ eter, natomiast wykazuje wrażliwość na formalinę oraz kwas solny. Można go inaktywować w autoklawie w temperaturze $121^{\circ} \mathrm{C}$ po 30 minutach oraz pod wpływem gotowania przez pięć minut i wystawieniu na promieniowanie UV [10].

Pielęgniarka wraz z lekarzem jako zespół interdyscyplinarny, udzielając wieloaspektowej porady, powinni rozważyć wiele czynników, które mogą zdarzyć się podczas podróży, oszacować zagrożenia i zminimalizować jego wystąpienie. Skala tego ryzyka jest jednak zależna od wielu warunków podroży, takich jak: region świata, klimat, pogoda, charakter i długość pobytu, rodzaj zakwaterowania oraz ogólne narażenie na różnego rodzaju czynniki infekcyjne. Należy zwrócić również uwagę na wiek osoby podróżującej oraz na występowanie chorób współistniejących. Częścią porady powinien być instruktaż dotyczący pierwszej pomocy i przekonanie osoby podróżującej o konieczności posiadania odpowiedniego ubezpieczenia. Jednym z najważniejszych elementów profilaktyki przy wyjazdach do stref endemicznego zagrożenia WZW A jest znajomość dróg zakażeń wirusem, objawów choroby oraz miejsc występowania na świecie. Podkreślić należy, że do zakażenia HAV dochodzi najczęściej drogą pokarmową, za pośrednictwem nieuzdatnionej wody, dlatego należy zwrócić szczególną uwagę na wodę wykorzystywaną do mycia produktów spożywanych na surowo lub produkcji kostek lodu. Zaleca się także stosowanie odpowiedniego ubrania z włókien naturalnych, unikanie kąpieli w akwenach słodkowodnych (szczególnie stojących) [11].

\section{Podsumowanie}

Prawidłowe rozpoznanie zakażeń wirusem nierzadko nastręcza trudności z powodu skąpoobjawowego i niecharakterystycznego obrazu klinicznego. Jednak wczesne rozpoznanie WZW typu A umożliwia wdrożenie skutecznego leczenia i zapobiega przenoszeniu się wirusa na kolejne osoby. Działaniami ograniczającymi to zagrożenie są w szczególności:

1. Szkolenie pracowników medycznych w zakresie diagnostyki i wczesnego wykrywania choroby.

2. Skuteczne stosowanie profilaktyki nieswoistej, w szczególności nauka społeczeństwa prawidłowej higieny rąk.

3. Promocja dostępnych szczepień ochronnych [12].

\section{Piśmiennictwo}

1. Bilski B, Wysocki J. Wirusowe zapalenie wątroby, jako choroba o podłożu zawodowym. Med Pr. 2001; 52, 3: 211-219.

2. https://medycynatropikalna.pl/choroba/wzw-typu-a [12.03.21r].

3. Baumann-Popczyk A. Wirusowe zapalenie wątroby typu A w Polsce w 2011 roku. Przegl Epidemiol. 2013; 67: 347-348.

4. Wasley A, Feinstone SM. Hepatitis A virus. W: Mandell GL, Bennett JE, Dolin R (red.). Principles and Practice of Infectious Diseases. Wyd. 7. Churchill Livingstone Elsevier, Philadelphia. 2010; 173: 2367.

5. Sikorska K. Wybrane aspekty kliniczne WZW A w czasie epidemicznego wzrostu zachorowań na terenie województwa gdańskiego w latach 1991-1993. Przegl Epidemiol. 2003; 57: 481-489.

6. Lemon SM, Ott JJ, Van Damme P, Shouval D. Type A viral hepatitis: A summary and update on themolecular virology, epidemiology, pathogenesis and prevention. $\mathrm{J}$ Hepatol. 2018; 68: 167-184.

7. Herold G. Medycyna wewnętrzna. Repetytorium dla studentówi lekarzy. PZWL, Warszawa 2004; 611-627.

8. Duszczyk E. Wirusowe zapalenie wątroby typu A - epidemiologia, klinika, leczenie, zapobieganie. Przew Lek. 2001; 4: 64-67.

9. Oddział Epidemiologii PSSE w Poznaniu. Powiatowa Stacja Sanitarno-Epidemiologiczna w Poznaniu. [dostępne] http:// www.szpital-strusia.poznan.pl/wp-content/uploads/aktualnosci/2017/Ulotka-wzw-A.pdf [10.03.21r]. 
10. http://www.prometeusze.pl/hav/ [23.03.21r].

11. Simon K, Ciaś J. Profilaktyka zakażeń wirusami pierwotnie hepatotropowymi przy wyjazdach do strefy tropikalnej. Fam Med Primary Care. 2012; 14,2: 280-285.

12. Klamann J, Smiatacz T. Diagnostyka wirusowych zapaleń wątroby w praktyce lekarza pierwszego kontaktu. Forum Med Rodz. 2016; 10, 2: 66-72.

Artykuł przyjęty do redakcji: 02.04.2021.

Artykuł przyjęty do publikacji: 17.08.2021.

Źródło finansowania: Praca nie jest finansowana z żadnego źródła. Konflikt interesów: Autorzy deklarują brak konfliktu interesów.
Adres do korespondencji:

Ewelina Krupowicz

ul. Marii Skłodowskiej-Curie 7A

15-096 Białystok

e-mail: ewelinakimszal@gmail.com

Zakład Zintegrowanej Opieki Medycznej, Wydział Nauk o Zdrowiu, Uniwersytet Medyczny w Białymstoku 